\title{
NOTE
}

\section{Virus-like particles associated with mass mortalities of the pen shell Atrina pectinata in Japan}

\author{
Yukio Maeno ${ }^{1, *}$, Tatsuya Yurimoto ${ }^{1}$, Hiroshi Nasu $^{2}$, Shiro Ito ${ }^{3}$, Noboru Aishima ${ }^{4}$, \\ Tomomasa Matsuyama ${ }^{5}$, Takashi Kamaishi ${ }^{5}$, Norihisa Oseko ${ }^{5}$, Yasunori Watanabe ${ }^{6}$ \\ ${ }^{1}$ Seikai National Fisheries Research Institute, Fisheries Research Agency, Taira, Nagasaki 851-2213, Japan \\ ${ }^{2}$ Kumamoto Prefectural Fisheries Research Center, Oyanonaka, Kami-Amakusa, Kumamoto 869-3603, Japan \\ ${ }^{3}$ Saga Prefectural Fisheries Division, Jonai, Saga 840-8570, Japan \\ ${ }^{4}$ Fukuoka Fisheries and Marine Technology Research Center, Freshwater Laboratory, Yamada, Asakura, Fukuoka 838-1306, \\ Japan \\ ${ }^{5}$ National Research Institute of Aquaculture, Fisheries Research Agency, Minami-Ise, Mie 516-0193, Japan \\ ${ }^{6}$ National Research Institute of Fisheries and Environment of Inland Sea, Fisheries Research Agency, Maruishi, Hatsukaichi, \\ Hiroshima 739-0452, Japan
}

\begin{abstract}
Mass mortalities of the pen shell Atrina pectinata occurred in the fishing grounds of Ariake Bay, in southwestern Japan, during late spring and summer in 2003 and 2004. Histological examination revealed extensive necrosis in the epithelial cells of the kidney and gill, and impairment of the endothelial cells of the mantle arteria. Although cestode larvae belonging to the genus Tylocephalum were found in the mantle, adductor muscle, kidney, and digestive gland, their prevalence and the intensity of infection were low. Examinations of moribund pen shells for Haplosporidium spp. infection using PCR analysis and for Perkinsus spp. infection using Ray's fluid thioglycollate medium were negative. Unenveloped virus-like particles were detected by transmission electron microscopy in the cytoplasm of affected kidney and gill cells of moribund pen shells. They were icosahedral spherical and 50 to $55 \mathrm{~nm}$ in diameter. These virus-like particles found in moribund pen shells are different from those described in other marine mollusks, and may be the causative agent of the mass mortalities of pen shells.
\end{abstract}

KEY WORDS: Bivalve $\cdot$ Pen shell $\cdot$ Atrina pectinata $\cdot$ Virus-like particles $\cdot$ Histology $\cdot$ Transmission electron microscopy

Resale or republication not permitted without written consent of the publisher

\section{INTRODUCTION}

Marine shellfish of the family Pinnidae are popular food sources and of high commercial value in the Asian Pacific area. Among these species, the pen shell Atrina pectinata Linnaeus, 1758 is one of the commercially most important taxa, especially in southwestern Japan. The pen shell fishery is centered in Ariake Bay on
Kyushu Island, and a wet weight of $13395 \mathrm{t}$ of pen shell was harvested in 1976. However, since 1992, the production has rapidly decreased, totaling as little as 37 t in 1999 (Kawahara \& Ito 2003). Recently, high mortality rates (60 to $90 \%$ ) have been observed, mainly between late spring and early autumn, in most of the major fishing grounds in Ariake Bay, resulting in a devastating impact on the pen shell fishery in this area 
(Kawahara et al. 2004a). Although there have been other reports of high mortality in this area (Kawahara \& Ito 2004, Kawahara et al. 2004b), the cause has not yet been determined. Few bivalve pathogens have been described in Ariake Bay. In a PCR survey, however, marine birnaviruses were detected in jackknife clam Sinonovacula consticta, Manila clam Tapes philippinarum, subcrenated ark shell Scapharca subcrenata and granular ark Tegillarca granosa (Suzuki \& Nojima 1999), and Haplosporidium spp. were detected in Pacific oyster Crassostrea gigas (Dr. M. Hamaguchi pers. comm.).

Mass mortalities of pen shells occurred in exploited natural beds in the northeastern Ariake Bay during late spring and summer in 2003 and 2004. Here, we describe the ultrastructural characteristics of the viruslike particles detected in these moribund pen shells.

\section{MATERIALS AND METHODS}

Pen shells. A total of 114 pen shells Atrina pectinata (102 to $223 \mathrm{~mm}$ shell length) were collected by divers from the northeastern part of Ariake Bay, from May to August 2003 and June to September 2004.

Histopathology. Mantle, adductor muscle, kidney, heart, gill, digestive gland, and gonad tissues from all sampled pen shells were fixed in $10 \%$ seawater formalin solution and embedded in paraffin wax. For histopathological analyses, $4 \mu \mathrm{m}$ sections were processed according to standard techniques and stained with Mayer's hematoxylin and eosin (H\&E).

Transmission electron microscopy (TEM). For TEM, the mantle, kidney, and gill tissues of 14 moribund pen shells were fixed in a mixture of $2.5 \%$ glutaraldehyde and $2 \%$ paraformaldehyde, and post-fixed with $1 \%$ osmium tetroixide. They were dehydrated in an ascending (50 to $100 \%$ ) ethyl-alcohol series, and embedded in Quetol 812 (Nisshin EM). Sections were stained with $1 \%$ uranyl acetate and $1 \%$ lead citrate, and examined with an electron microscope (JEOL-100S).

Assay for Haplosporidium nelsoni and $\boldsymbol{H}$. costale by nested PCR. Genomic DNA was extracted from the mantle, adductor muscle, kidney, gill, and digestive gland of 5 moribund pen shells following a general method using Proteinase $\mathrm{K}$ and phenol-chloroform. The extracted DNA was amplified by PCR with universal primers for the SSU rRNA genes of eukaryotes: 5'-18S (CGACAACCTGGTTGATCCTGCCAGT) and 3'-18Sr (TTGATCCTTCTGCAGGTTCACCTAC). PCR amplification was attempted using paired primers designed to target gene sequences specific to $H$. nelsoni (ACATTCGGGATCCAGACAACTTTTGTT and ATGTGTTGGTGACGCTAACCGATG; Kamaishi \& Yoshinaga 2002) and H. costale (CTCAGTCTC-
GATCCCTGGCTCCCGCCC and GAACAAGCGCTAGCAGTACATCGC; Stokes \& Burreson 2001). Cycling parameters were determined following a method reported previously (Kamaishi \& Yoshinaga 2002). The PCR products were analyzed by agarose gel electrophoresis and stained with ethidium bromide. The positive control was from the source of DNA used by Kamaishi \&Yoshinaga (2002).

Assay for Perkinsus sp. using Ray's fluid thioglycollate medium (RFTM). The gills and mantles of 20 moribund pen shells were incubated in the dark for $8 \mathrm{~d}$ at $20^{\circ} \mathrm{C}$ in RFTM containing $350 \mu \mathrm{g} \mathrm{ml}^{-1}$ penicillin $\mathrm{G}$ potassium, and $700 \mu \mathrm{g} \mathrm{ml}^{-1}$ of streptomycin sulfate to induce the formation of prezoosporangia in accordance with a method described previously (Maeno et al. 1999). The incubated pieces were stained with $20 \%$ Lugol's iodine solution for detection of prezoosporangia, and were observed under a microscope. As a positive control, Manila clams infected with Perkinsus sp. were used.

\section{RESULTS}

\section{Pen shells}

Out of 114 pen shells Atrina pectinata, 49 (43\%) were moribund. Moribund pen shells exhibited palegray pigmentation of the adductor muscle and visceral mass. At necropsy, atrophy of the mantle, adductor muscle, and visceral mass was observed.

\section{Histopathology}

Cestode larvae Tylocephalum sp. were seen in the muscular tissues of the mantle and adductor muscle (Fig. 1) and in the connective tissues of the kidney and digestive gland of the pen shells. The parasites had an elliptical shape with a snout at one end and contained granular matter. Cestode larvae were present in 34 out of 114 pen shells $(29.8 \%)$, at very low intensity. No other parasites (including Haplosporidium spp. and Perkinsus spp.) were observed.

Histological lesions were observed in the mantle, kidney, and gill. The mantle showed impairment of endothelial cells of the arteria, infiltration of hemocytes, and dead cell debris and eosinophilic fibrosis in the connective tissue (Fig. 2). The cell borders of the renal epithelial cells were indistinct, and extensive and severe necrosis and pycnotic changes were found (Fig. 3). Eosinophilic material and vacuoles were also found in the cytoplasm of renal epithelial cells. The gill filaments were destroyed in moribund pen shells (Fig. 4), and localized sloughing resulted from degra- 


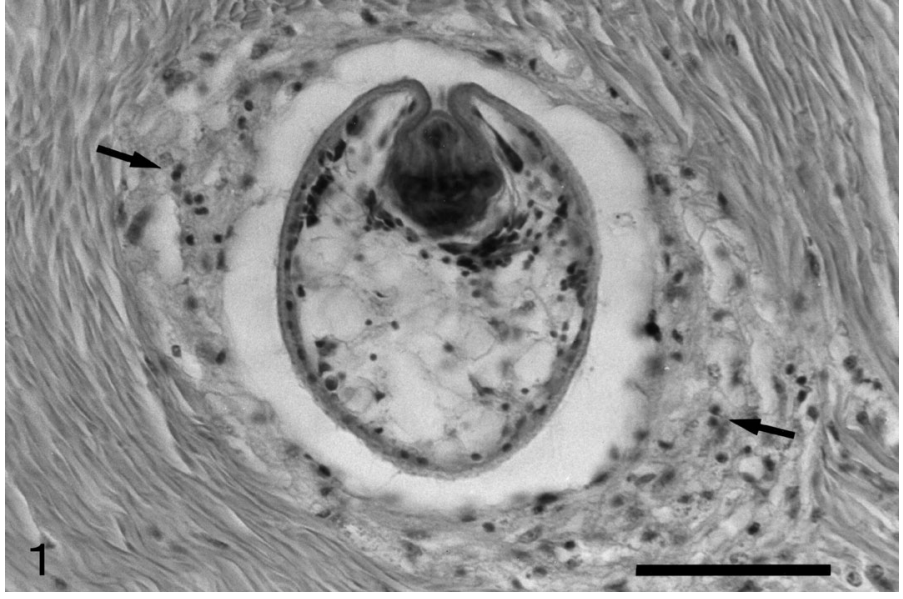

Fig. 1. Atrina pectinata. Tylocephalum sp. in the adductor muscle of a pen shell. Hemocytes (arrows) infiltrated the affected tissue surrounding the parasite; H\&E (hematoxylin and eosin) staining. Scale bar $=50 \mu \mathrm{m}$

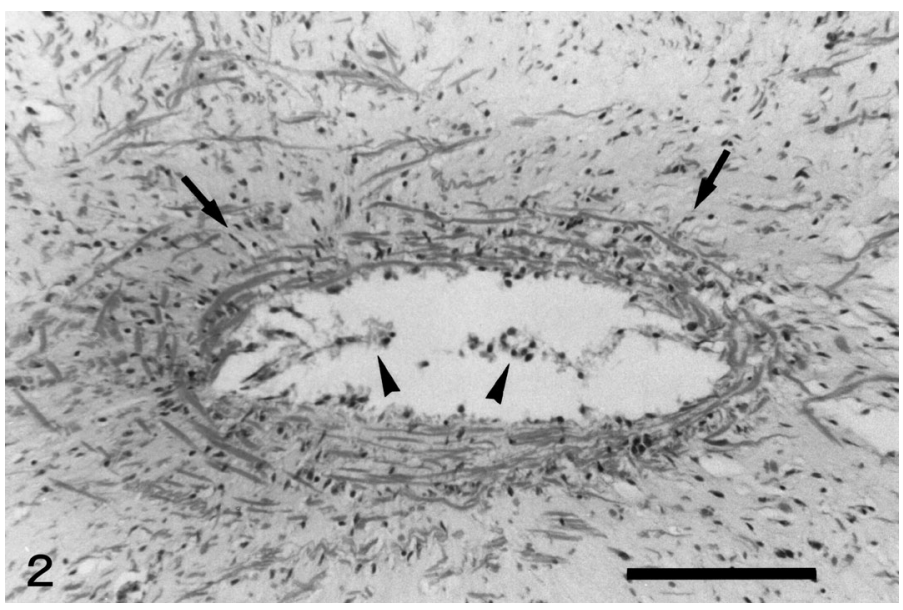

Fig. 2. Atrina pectinata. Light micrograph showing histological lesions in the endothelial cells of the mantle arteria, with necrotic debris (arrowheads) and infiltration of hemocytes (arrows); H\&E staining. Scale bar $=100 \mu \mathrm{m}$

dation of the epithelium. No lesions were observed in the adductor muscle, digestive gland, heart, or gonads.

\section{TEM}

Virus-like particles were observed in the cytoplasm of renal epithelial cells (Fig. 5) and gill epithelial cells (Fig. 6) of all moribund pen shells examined. They appeared free in the cytoplasm or associated with cytoplasmic vesicles. The virus-like particles were icosahedral spherical, 50 to $55 \mathrm{~nm}$ in diameter, and had no envelope. The nuclei of infected cells were often dis-

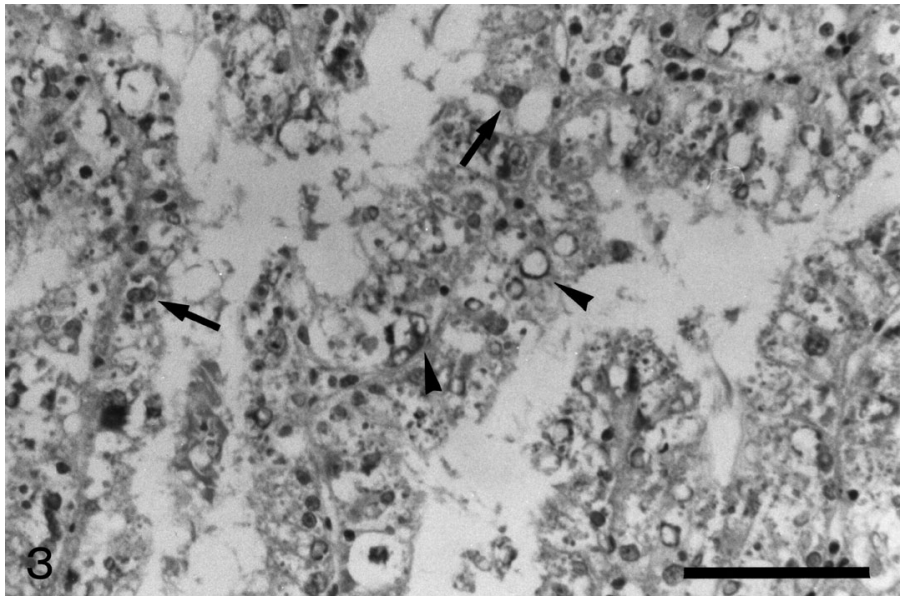

Fig. 3. Atrina pectinata. Light micrograph showing extensive necrosis in the renal epithelial cells. Eosinophilic material (arrows) and vacuoles (arrowheads) found in the cytoplasm of affected cells; H\&E staining. Scale bar $=100 \mu \mathrm{m}$

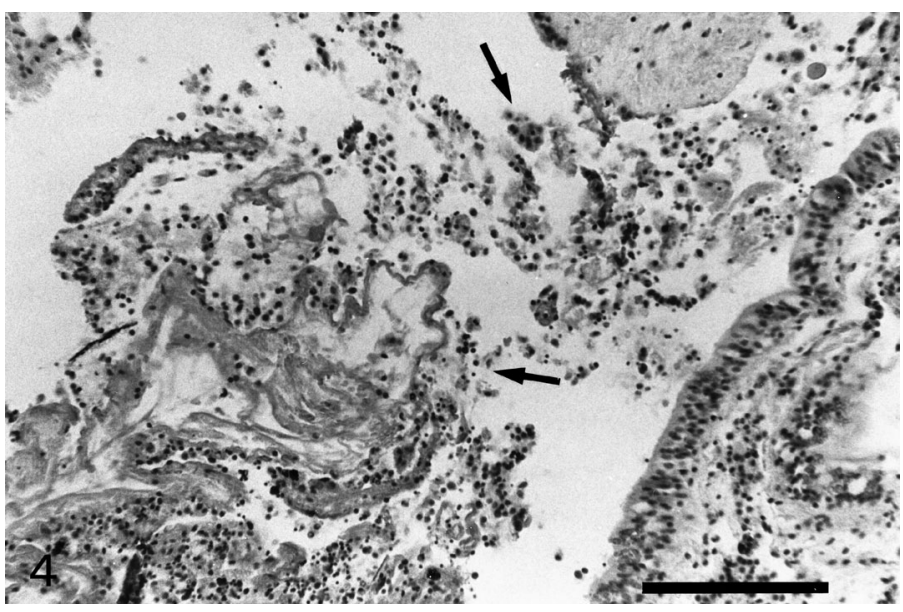

Fig. 4. Atrina pectinata. Light micrograph showing extensive necrosis (arrows) in the epithelial cells of the gill; H\&E staining. Scale bar $=100 \mu \mathrm{m}$

placed to the periphery of the cell owing to replication of the virus-like particles. The cytoplasmic content of affected cells was often reduced compared with that of uninfected cells.

\section{Assays for Haplosporidium nelsoni, $H$. costale, and Perkinsus spp.}

All of the pen shells examined for the presence of the parasites Haplosporidium nelsoni and $H$. costale by means of nested PCR and for Perkinsus spp. using RFTM were negative. 


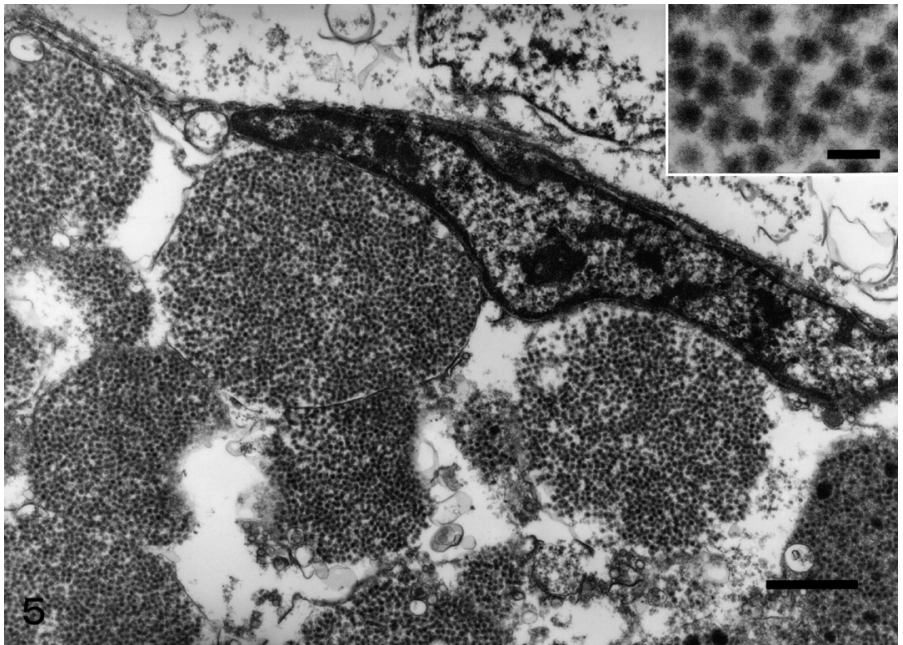

Fig. 5. Atrina pectinata. Virus-like particles in the cytoplasm of renal epithelial cells. Scale bar $=1 \mu \mathrm{m}$. Inset shows virus-like particles at higher magnification. Scale bar $=100 \mathrm{~nm}$

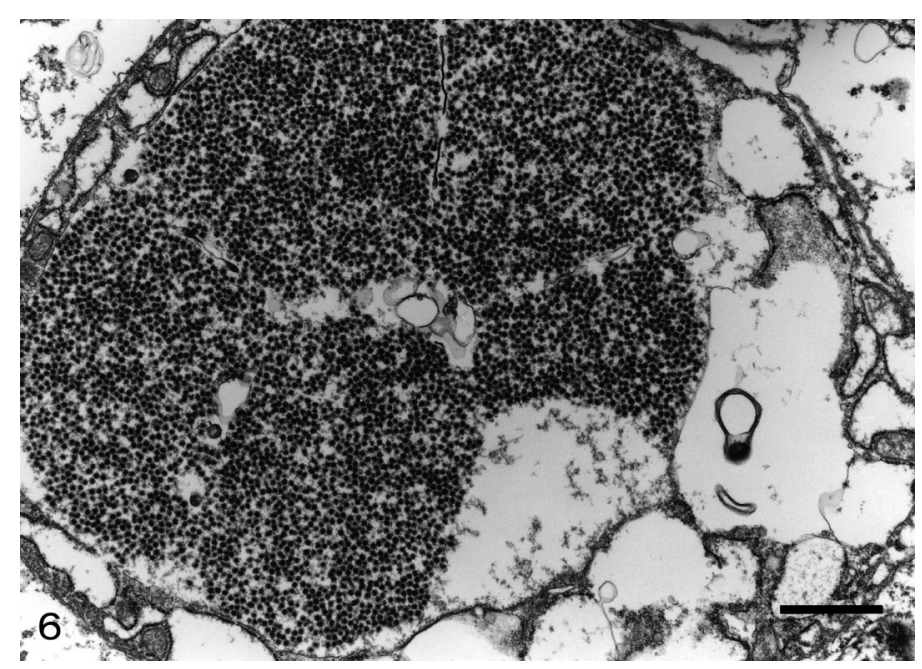

Fig. 6. Atrina pectinata. Virus-like particles in the cytoplasm of gill epithelial cells. Scale bar $=1 \mu \mathrm{m}$

\section{DISCUSSION}

Histological observations revealed metazoan parasites in the mantle, adductor muscle, kidney, and digestive gland of pen shells Atrina pectinata. Based on their morphological characteristics, they were cestode larvae belonging to the genus Tylocephalum (Cake 1976). However, because all the cestode larvae in these tissues were completely encapsulated with hemocytes derived from the host and neither their prevalence among pen shells nor their infection intensity was high, parasitism of cestode larvae was ruled out as a cause of the mass mortality.
In the pen shell, the function of the kidney in regulating blood components is to reabsorb most free amino acids and some ions from the urine and to concentrate accumulated waste (e.g. ammonia) in the urine and then eliminate it (Suzuki 1988). In general, the gills of bivalves play an important role in respiration and feeding: gas exchange takes place across the walls of the gill filaments, and suspended particles are removed from the water by cilia on the gills (Gosling 2003). In affected pen shells, marked histological lesions were observed in the epithelium of the kidney and gills, and these changes may be relevant to functional deficiency in the organs of pen shells that have suffered mortality of unknown etiology.

Ultrastructurally, virus-like particles were observed in the cytoplasm of the epithelial cells of the kidney and gill of moribund pen shells. Virus-like particles associated with mortalities have been reported in several marine mollusks, such as mussels (Rasmussen 1986, Jones et al. 1996), clams (Hine \& Wesney 1997 , Novoa \& Figueras 2000), scallops (Hine \& Wesney 1997), cockles (Carballal et al. 2003), pearl oysters (Pass et al. 1988, Comps et al. 1999), and abalone (Otsu \& Sasaki 1997). The size, morphology, and replication of the virus-like particles in the cytoplasm, in association with cytoplasmic vesicles, in the pen shell differ from those described previously in marine mollusks. This paper is the first description of virus-like particles in the pen shell.

High mortality rates in pen shells still continue in the major fishing grounds of Ariake Bay. Further studies are urgently needed to identify the virus-like particles and to determine whether they are responsible for the mass mortalities that occurred. Such studies are in process in our research group.

\section{LITERATURE CITED}

Cake EW Jr (1976) A key to larval cestodes of shallow-water, benthic mollusks of the northern Gulf of Mexico. Proc Helminthol Soc Wash 43:160-171

Carballal MJ, Villalba A, Iglesias D, Hine PM (2003) Viruslike particles associated with large foci of heavy hemocytic infiltration in cockles Cerastoderma edule from Galcia (NW Spain). J Invertebr Pathol 83:234-237

Comps M, Herbaut Ch, Fougerouse A (1999) Virus-like particles in pearl oyster Pinctada margaritifera. Bull Eur Assoc Fish Pathol 19:85-88

Gosling E (2003) Bivalve molluscs-biology, ecology and culture. Blackwell, Oxford, p 7-43

Hine PM, Wesney B (1997) Virus-like particles associated with cytopathology in the digestive gland epithelium of scallops Pecten novaezelandiae and toheroa Paphies ventricosum. Dis Aquat Org 29:197-204

Jones JB, Scotti PD, Dearing SC, Wesney B (1996) Virus-like particles associated with marine mussel mortalities in New Zealand. Dis Aquat Org 25:143-149

Kamaishi T, Yoshinaga T (2002) Detection of Haplosporidium nelsoni in Pacific oyster Crassostrea gigas in Japan. Fish 
Pathol 37:193-195

Kawahara I, Ito S (2003) Mortality of pen-shells, Atrina pectinata in northeast part fishery of Ariake Sound in summer, 2000 and 2001. I. Occurrence of mortality. Bull Saga Pref Ariake Fish Res Dev Cent 21:7-13

Kawahara I, Ito S (2004) Characteristics of the parasitic cestode Tylocephalum sp. infecting the adductor muscle of the pen-shell, Atrina pectinata. Bull Saga Pref Ariake Fish Res Dev Cent 22:25-28

Kawahara I, Ito S, Chikushi Y, Aishima N, Kitamura H (2004a) Mortality of pen-shells, Atrina pectinata in northeast part fishery of Ariake Sound. II. Bull Saga Pref Ariake Fish Res Dev Cent 22:17-23

Kawahara I, Ito S, Yamaguchi A (2004b) Influence of the bullnose ray, Aetobatus flagellum, on the pen-shell, Atrina pectinata, in Ariake Sound. Bull Saga Pref Ariake Fish Res Dev Cent 22:29-33

Maeno Y, Yoshinaga T, Nakajima K (1999) Occurrence of Perkinsus species (Protozoa, Apicompexa) from Manila clam Tapes philippinarum in Japan. Fish Pathol 34: $127-131$

Novoa B, Figueras A (2000) Virus-like particles associated

Editorial responsibility: Albert K. Sparks,

Seattle, Washington, USA with mortalities of the carpet-shell clam Ruditapes decussates. Dis Aquat Org 39:147-149

Otsu R, Sasaki K (1997) Virus-like particles detected from juvenile abalone (Nordotis discus discus) reared with an epizootic Fatal Wasting disease. J Invertebr Pathol 70: 167-168

Pass DA, Perkins FP, Dybdahl R (1988) Virus-like particles in the digestive gland of the pearl oyster (Pinctada maxima). J Invertebr Pathol 51:166-167

Rasmussen LPD (1986) Virus-associated granulocytomas in the marine mussel, Mytilus edulis, from three sites in Denmark. J Invertebr Pathol 48:117-123

Stokes NA, Burreson EM (2001) Differential diagnosis of mixed Haplosporidium costale and Haplosporidium nelsoni infections in the eastern oyster, Crassostrea virginica, using DNA probes. J Shellfish Res 20:207-213

Suzuki S, Nojima M (1999) Detection of a marine birnavirus in wild molluscan shellfish species from Japan. Fish Pathol 34:121-125

Suzuki T (1988) Ultrastructure of the excretory organs and urinary component of the marine bivalve, Atrina ( $S$.) pectinata. Comp Biochem Physiol A 90:79-83

Submitted: July 14, 2005; Accepted: February 20, 2006

Proofs received from author(s): June 26, 2006 